\title{
Post-Zionist Perspectives on Contemporary Israel
}

\section{JAN SELBY}

During the late 1980s and early 1990s Israeli social science went through something of a transformation. Previously, its sociology had been dominated by a conservative neofunctionalism that attributed a high degree of value consensus to Israeli society, but had little to say about internal social conflicts or inequalities, while its history had been strongly informed by nationalist myths about the formation of the Israeli state, its relations with neighbouring Arab states and the flight of Palestinian refugees during the 1948-9 'war of independence'. 'Within the context of the tentative liberalisation of Israeli society, however, and spurred on by the developing Arab-Israeli peace processes, much of this started to change. A raft of 'New Historians' questioned whether the Palestinians had indeed fled, or whether, to the contrary, they had been purposefully transferred and expelled by Israeli forces. ${ }^{2}$ 'Post-Zionist' sociologists sought to distance themselves from long-standing Zionist narratives, as well as to draw insights from poststructuralist social theory and postcolonial studies, in order to explore issues of discourse, power and identity in the Israeli-Palestinian arena. ${ }^{3}$ Still others argued that Israel had never been socialist at all, but had, to the contrary, from its inception been a quasi-fascist and anti-socialist society. ${ }^{4}$ In all of these respects, and whatever its limitations, this new scholarship brought forth significant challenges to hitherto mainstream understandings of Israeli economy, history and society.

Now, for the first time, several works have appeared which seek to provide comprehensive accounts of Israeli society from a post-Zionist (or non-Zionist) perspective. Both Baruch Kimmerling in The Invention and Decline of Israeliness and Gershon Shafir and Yoav Peled in Being Israeli attempt to synthesise recent post-Zionist scholarship and articulate new paradigms for the study of Israeli society, the one from a Weberian and the others from a Gramscian perspective. ${ }^{5}$ Meanwhile, in The Global Political Economy of Israel, Jonathan Nitzan and 
Shimshon Bichler develop a startling Veblenian-Marxist account of Israeli society and its integration into the global economy that dispenses with all of the prevailing orthodoxies on the subject. ${ }^{6}$ Taken together, these works serve as useful lenses for analysing the changing nature of Israel's political economy and society, as well as the roots of the Israeli-Palestinian conflict and the merits and limitations of the authors' divergent theoretical perspectives.

Kimmerling's central thesis is that the monocultural regime established under the young Israeli state has given way to a segmented and pluralistic polycultural society, within which there is growing conflict 'over the meaning of what might be called Israeliness'. ${ }^{7}$ Israel, Kimmerling holds, is now divided into seven major cultures or counter-cultures: the previously hegemonic Ashkenazi (that is, of European origin) secular upper middle class; the largely Ashkenazi national religious movement; the Mizrahi Jews (of Middle Eastern and North African origin); the non-Zionist Orthodox Haredim; the Arab minority within Israel; the Russian-speaking immigrants from the former USSR; and the Ethiopian immigrant population. These more or less discrete 'islands' of Israeli society each have their own distinctive cultural patterns of consumption, lifestyle, speech and apparel, their own sets of perceptions and beliefs, and their own separate institutional bases-whether in schools, in the print and broadcast media or in political parties. ${ }^{8}$ For Kimmerling, the roots of this cultural pluralism lie most importantly in the conquest and subsequent occupation of the West Bank and Gaza. ${ }^{9}$ The occupation, he argues, inspired deep religious sentiments, leading to the rise of the national religious Gush Enumin movement for the settlement of the Occupied Territories; the fragmentation of the hitherto largely secular monocultural regime; and a general 'turn from a more civic and citizenship-based identity towards a Jewish ethnocentric primordialism' ${ }^{10}$ The 1967 war, in short, caused 'social chain reactions', which, in addition to the slow and incremental empowerment of population groups and the arrival of new immigrant populations, led to the emergence of a 'new polycultural, multivocal, multiracial Israeliness'. ${ }^{11}$ What remains from the previous monocultural regime, Kimmerling argues, are just two powerful 'metacultural codes'-Jewishness and security. ${ }^{12}$ Thus, on the one hand, Israel remains an essentially Jewish state and society, an 'ethnocracy' in which the 'basically undemocratic nature of the Israeli regime' is 'compulsively and systematically' denied; on the other, it is a society in which the values, practices and institutions of a 'military-cultural complex' are so dominant that security is no less than a 'civil religion'. ${ }^{13}$

While much of this is instructive, especially in its emphasis on the ethnocratic and militaristic character of Israeli society, there are at least three characteristically Weberian problems with Kimmerling's account. First, Kimmerling completely fails to address the political economy of the formation and transformation of Israeli society. He sees Zionism as 'a uniquely nonprofit and noneconomic settler movement' driven exclusively by nationalist sentiment, the result being that he ends up saying nothing either about the world-systemic colonial context within which the Zionist movement took shape, or about the political economy of settlement within Ottoman and British Mandate Palestine (which was crucial to Israeli state formation, as we shall see below). ${ }^{14} \mathrm{He}$ provides only sporadic mention of the class structure of Israeli society and says nothing at all about the 
impacts of domestic economic change, growing economic inequality and Israel's deepening integration into the global economy on the cultural cleavages which are his primary focus. Moreover, while he recognises that the Israeli economy has recently become dominated by a small number of conglomerates, he fails to square this growing concentration of ownership with his characterisation of Israeli society as increasingly pluralistic. ${ }^{15}$ Thus Kimmerling notes, quite correctly, that an Ashkenazi elite 'still maintains primary control of large businesses, commerce and industry, the media establishment, and the upper echelons of the armed forces and of higher education', yet apparently sees no contradiction between this and his view of Israeli society as consisting of seven autonomous cultures 'without an accepted hierarchy between them'. 16

A second problem with Kimmerling's account lies in its inadequate theorisation of the relations between the Israeli state and Israeli society. Like so many Weberians beholden to the idea of 'bringing the state back in', Kimmerling is preoccupied with the question of the strength and autonomy of the state relative-and in opposition-to society. ${ }^{17}$ Moreover, like his one-time collaborator Joel Migdal, Kimmerling sees Israel as a 'strong state' with a 'high capacity to recruit internal human and material resources for collective goals' ${ }^{18}$ He views this strong state as actively engaged in assigning tasks to the population and in excluding certain groups from the political process, in accordance with its own 'best interests' and 'ends'. 19 And he argues that since 1967 'the autonomy of the state has continually diminished in the face of ideological groups that stress its "primordial Jewish" identity', and further that 'Israel is presently facing a situation of somewhat diminishing "stateness", ${ }^{20}$ Yet this is profoundly misleading for, in reality, the supposed 'autonomy' of the Israeli state prior to 1967 is a mirage resulting from the erstwhile social hegemony of Labour Zionism. From the pre-state days until the 1970s, Yishuv and Israeli society were dominated by the Ashkenazi-led Labour Zionist movement, which espoused a mixture of secular, socialist, nationalist and pioneering values, and found institutional expression in the kibbutzim, the Histadrut labour federation, the paramilitary Haganah (which formed the basis for the Israeli Defence Forces) and the leftwing political parties which led every Israeli government until 1977, when Menachem Begin's Likud-led coalition came to power. It was this hegemony of the Labour Zionist movement, rather than any interests of the state itself, which produced the largely secular conception of Jewish identity which prevailed before 1967. Equally, the seeming decline in the 'autonomy' of the Israeli state since then is but a product of the withering of Labour Zionist hegemony.

The third and root problem here is that Kimmerling is not critical enough either of traditional Zionist narratives or of contemporary Israeli society. Kimmerling has long been a strong critic of the Oslo peace process with the Palestinians and has recently produced powerful indictments of Israel's latest premiers, Ehud Barak and Ariel Sharon. ${ }^{21}$ But he combines this political outrage with a sociological worldview which veers between naivety and conservatism. Thus, on the one hand, he depicts Israel as a liberal multicultural society in the making, in which demographic change will incrementally spill over into other spheres and contribute to the rapid pluralization of the Israeli state'-this optimistic assessment being one that flies in the face of deepening economic hierarchies 
and inequalities. ${ }^{22}$ Yet, on the other hand, he seems to regret the dissolution of Israel's Labour-led monocultural regime and to bemoan Israel's current 'lack' of a 'finalized and consensual geopolitical and social identity', it being 'unfortunate', he says, that there is 'no commonly agreed upon replacement for the national identity' of the $1950 \mathrm{~s} .{ }^{23}$ Like the neofunctionalist sociologists who went before him, Kimmerling overstates the consensual unity and completedness of the young Israeli society; pays insufficient attention to the power relations that lay behind its formation; and understands 'Israeliness' - as his title suggestsin essentialist and implicitly Ashkenazi terms. Moreover, like those neofunctionalist writers who interpreted Israel in the wake of the 1967 war as facing a "crisis of over-burden' (with the basic premises that pre-1967 Israel was consensual, and that the 1967 war marked the key watershed in the evolution of Israeli society), so too Kimmerling traces the transformation of Israel from the "crosspressures' produced by the conquest of the West Bank and Gaza. ${ }^{24}$ Thus, while Kimmerling claims to articulate a new approach to the study of Israeli society, the influence of its nationalist sociologies clearly remains. All in all, Invention and Decline unfortunately gives ample support to Nitzan and Bichler's dismissal of post-Zionism as little more than 'new wine in old bottles' ${ }^{25}$

Nitzan and Bichler's own account of Israeli society, by contrast, is highly original and not in the least bit conservative. Unlike Kimmerling, whose comments on transnational processes are limited to wars and immigration, Nitzan and Bichler stress the extent to which Israel's domestic political economy is determined by, and has been integrated into, regional and global inter-capitalist relations. Moreover, and equally unlike Kimmerling, Nitzan and Bichler view contemporary Israel as characterised not by pluralism, but by a growing concentration of power in the hands of a small and nepotistic ruling class. Drawing upon the neoMarxist monopoly capital tradition, as well as Thorstein Veblen's discussion of the ways in which modern businesses attempt to 'sabotage' production in order to maximise profits, Nitzan and Bichler develop a novel financial (as against productionist) theory of capital. ${ }^{26}$ The 'compass of modern capitalism', they argue, is 'differential accumulation', it being the aim of all capitalist enterprises not to maximise profits in absolute terms but to beat the average rate of capital income within an economy and thereby increase their overall share of economic and social power. ${ }^{27}$ Capitalism, they hold, is 'not run by most people, but by a relatively small number of very large capitalists', it thus being the structures and strategies of the ruling class - or what they call 'dominant capital' - that determine patterns of political, economic and social change. ${ }^{28}$ On this basis, Nitzan and Bichler argue that Israeli society has been dominated ever since its inception by a close-knit and endogamous ruling class, an 'octopus-like structure' with arms that move freely between government, business and the military. ${ }^{29}$ Ever since the Yishuv, they contend, power has become more and more concentrated, such that from the early 1970s Israel has become home to a 'dual political economy'-comprising an oligopolistic big business sector, dominated by just five major corporate groups and controlling 'almost every significant business activity', and a competitive small-business sector wholly subordinate to it. ${ }^{30}$

Nitzan and Bichler argue that, up until these years, the growing power of Israel's 'dominant capital' was premised on its enjoyment of a disproportionate 
share of the benefits of rapid economic growth (between 1922 and 1973, Yishuv/ Israeli gross national product increased by an astounding factor of 250). ${ }^{31}$ But, as growth started to falter, dominant capital began to explore other avenues for accumulation. The same was simultaneously happening, Nitzan and Bichler contend, at a 'global level', the upshot_-both globally and within Israel-being the replacement of the previous 'breadth regime' of differential accumulation through economic growth by a 'depth regime' of 'accumulation through crisis'. ${ }^{32}$ This new regime was premised, they assert, on a high degree of international conflict in the Middle East, with recurrent conflicts in 1973, 1979-88 and 1990-1 helping to generate substantial oil price rises and profit windfalls, increased arms sales and domestic inflation (the latter resulting primarily from increased oil and arms prices). Nitzan and Bichler hold that during this period a 'weapondollarpetrodollar coalition' predominated within the developed capitalist world and that these conflict dynamics were so important during the 1970s and 1980s that the US and Israeli governments tended to promote high oil prices, militarisation and political instability across the Middle East, exactly the opposite of their publicly declared aims. ${ }^{33}$ They argue that the consequences within Israel were the militarisation of the Israeli political economy (domestic military procurement rose to an average of 23 per cent of gross domestic product between the mid 1960s and mid 1980s); a growing dependence on US financial and military assistance; the rise of right-wing religious nationalism and the concomitant decline of the Labour Party; and the further consolidation of the power of Israel's ruling class, which had neatly shifted to take advantage of increased arms sales and domestic inflation. ${ }^{34}$

Continuing their account, Nitzan and Bichler submit that, from the late 1980s, things started to change. The demise of Third World import substitution, the retreat of state ownership in the West, and the liberalisation and subsequent collapse of the Eastern bloc all provided fertile soil for a renewed global breadth regime. $^{35}$ The profits and relative power of the global oil and armaments sectors waned, to be replaced at the helm of dominant capital by the new information technology and communication (ITC) industries. Differential accumulation was now achieved not through crisis but through green-field expansion in emerging markets, as well as an increase in mergers and acquisitions. Israel in the process became a high-tech 'tiger economy', buoyed by the global return to breadth as well as by Russian immigration and mafia money. Israel's major corporate groups were transnationalised, such that a distinct 'Israeli dominant capital' no longer existed. ${ }^{36}$ Peace now became the preferred economic option, crucial to the Israeli ruling class's new strategy of attracting foreign investment and further integrating Israel into the global economy. For Nitzan and Bichler, the Arab-Israeli peace processes of the 1990s were essentially this ruling class's response to the 1990 s high-tech globalisation boom. ${ }^{37}$

Nitzan and Bichler argue further that, since the collapse of the 1990s boom and bubble, many of these developments have gone into reverse. The differential profitability of the global ITC sector has waned, creating new opportunities for accumulation through crisis. And, sure enough, renewed conflict has been the result both in Israel and the Occupied Territories, and in the Gulf. Oil prices have soared, and the oil and military sectors have recorded record absolute profits as well as a much-increased share of global profits. For Nitzan and 
Bichler, it is the global political economy of differential accumulation which is the major determinant of war and peace in the Middle East, and of transformations in Israeli society. As they say of the current situation in Israel-Palestine, this 'will not be settled in the streets of Nablus or the shacks of the Jenin refugee camps. The real war lays elsewhere, in the boardrooms of the multinationals where the vanguard of the arms and oil industries are leading a resurgence against the forces of the new global capital'. ${ }^{38}$

The Global Political Economy of Israel is a brilliant and disturbing book, as well as a surprisingly accessible and playful read. It operates on many levels, simultaneously providing a novel theory of capital accumulation and inter-capitalist competition, a fresh take on US imperial adventures in the Middle East and a history of the Israeli political economy. Its insistences on the centrality of big business within Israeli society, and on Israel's integration into global circuits of capital, are an important antidote to the culturalism and statism that so dominate discussions of the country; and it is full of challenging theses on subjects as varied as the roots of inflation and the incidence of corporate mergers, as well as wonderfully gossipy insights on the machinations of Israel's elites. Inevitably, though, a book of this ambition raises almost as many questions as it answers. Two issues warrant particular discussion here.

First, Nitzan and Bichler overstate the impacts of regional and global intercapitalist relations on Israel's political economy. They insist that changes in Israel's political economy-whether the expansion of its military sector and growth of religious nationalism during the 1970s or the onset of the high-tech boom and peace processes during the 1990s - have been 'largely dependent on global conditions'. ${ }^{39}$ They also contend that Israel has long been integrated into the Middle East, its 'domestic depth regime of militarized stagflation' being 'intimately linked to the regional cycle of energy conflicts'. ${ }^{40}$ They reach these verdicts on the strength of claimed statistical correlations between the Israeli, regional and global political economies. However, not only are these correlations themselves based on a questionable theory of accumulation, but, more importantly, the causal evidence, including that which they themselves marshall, does not provide sufficient grounds for these conclusions. ${ }^{41}$ Thus while Nitzan and Bichler argue that the Israeli economy has followed closely in step since the early 1970 s with a 'global' pattern of alternating 'breadth' and 'depth' regimes, it is clear that this putatively global pattern is modelled firmly on the US economy and diverges significantly from the patterns followed, for instance, by Germany and Japan. ${ }^{42}$ Equally, while they claim that Israel was intimately linked' into the regional energy conflicts of the 1970s onwards, there is scant evidence for this: of the 'energy conflicts' during this period Israel was only centrally involved in one (the 1973 war); and, furthermore, most of the major geopolitical incidents in which Israel was directly involved had negligible impacts on oil prices (most notably the 1978 and 1982 invasions of Lebanon, the 1978 Camp David Accords with Egypt, and the Palestinian intifada from 1987 - none of which receive much attention from Nitzan and Bichler).

Rather than being integrated into a regional dynamic of energy conflicts, the more conspicuous fact about the Israeli economy is its relative non-integration into the Middle Eastern regional economy (the Arab Boycott, which lies behind 
this, being something that Nitzan and Bichler also largely ignore). What seems clear, even from Nitzan and Bichler's own account, is that Israel's political economy bears the imprint less of general processes of regionalisation and globalisation, than of the historically specific relationship with the US that developed in the late 1960s. Moreover, what also seems clear is that geopolitical developments, like the invasions of Lebanon, were primarily driven not by regional political dictates, or even by Israel's close relationship with the US, but by uniquely domestic imperatives. ${ }^{43}$ Israel's leading corporations may recently have become integrated into a transnational network of capital, but the political economic relations that have made Israel what it is today are perhaps best thought of neither as global, regional or transnational, but as a complex mix of domestic and international determinations.

A further and even more fundamental problem with Nitzan and Bichler's account is its almost exclusive focus on dominant capital. At its core, Nitzan and Bichler's theoretical world seems to be inhabited purely by capitalists: 'capitalists', writes Nitzan, 'exert their power over society as a whole, so one whose profit amounts to one-hundredth of the total can be said to control 1 percent of the entire capitalist process'. ${ }^{44}$ The struggles and strategies of major corporations dominate the scene, while all else is relegated to the background context within which accumulation struggles take place. Nitzan and Bichler do recognise that dominant capital is 'never entirely synonymous' with the ruling class, and that Israel has not always been a capitalist society; and they also admit, for instance, that there are important country-specific labour relations which can have important repercussions for capital accumulation. ${ }^{45}$ But, boxed in by their ahistorical theoretical model with its sole focus on dominant capital and differential accumulation, Nitzan and Bichler end up saying very little either about the complex relations between the capitalist and non-capitalist interests of the Israeli ruling class, about what predated the 'progressive emergence' of Israeli capitalism, or even about conflicts and compromises between Israeli elites and the larger Israeli population. ${ }^{46}$ Instead, their analysis moves between a priori theorisations of the various means of differential accumulation, on the one hand, and micro-scale snippets of Israel's ruling class in action, on the other-without there being an awful lot in between. Their political economy includes not much by way of political sociology-and the consequence of this is that no great sense emerges of the structural specificity of Israeli society.

This weakness is especially apparent in Nitzan and Bichler's comments on the roots of Israeli statism. Nitzan and Bichler argue that centralised pre-state institutions emerged in the Yishuv so as to tackle labour shortages and create the social infrastructure necessary for profit-making, while Zionist ideals, with their characteristic mélange of nationalist, socialist and religious rhetoric, were invoked in order to legitimate and consolidate a capital-friendly social order. ${ }^{47}$ As their revealingly instrumentalist metaphor has it, "the Israeli state, while on the surface subjugating capital to its own ends, was in fact the initial "cacoon" within which capitalist institutions and organisations were allowed to develop'. ${ }^{48}$ Yet this is misleading, for the problem, so far as Jewish capitalists were concerned, was not that accumulation was impeded by a labour shortfall—since the local Arab population constituted a large pool of cheap labour-but that profit maximisation, 
left to its own accord, would have impeded the Zionist project of settling Palestine. Initially, as Gershon Shafir emphasises in his groundbreaking account of the formative period of Zionist colonialism, Jewish capitalists largely employed cheap Arab labour. ${ }^{49}$ Unwilling to lower their wage demands and thus compete directly with Arab workers, Jewish workers thus started campaigning for the exclusion of Arabs from the Jewish labour market. Eventually, this led to an accommodation between Zionist landowners and workers-what Michael Shalev has called a 'marriage of convenience between a settlement movement with settlers and a workers' movement without work' - which saw the creation of a 'split labour market', the emergence of a distinct Jewish economic sector and the formation of powerful central institutions like the Histadrut, which functioned to maintain and oversee this political economic regime. ${ }^{50}$ The distinctive features of pre-state Zionist society and the young Israeli state, in other words, developed not because they were functional 'cacoons' for capital, but out of the sociologically specific character of the Zionist colonial encounter with the Palestinians: namely, the lateness of the colonial encounter in Palestine, the presence there of a mostly settled population and large rival workforce, and the Zionists' commitment - in contrast to most of the late colonial projects in Africa and the Middle East- to physical settlement. If capital accumulation really had been as fully in charge as Nitzan and Bichler contend, the Israeli state would never have come into existence.

The pertinence of this in the present context is that the distinctive political economic and institutional forms that were first negotiated in the early twentieth century came to structure Israeli society right up to the 1970s, and in certain respects still do. Shafir and Peled's Being Israeli traces these structural continuities from the pre-state days to the present. The political economy of colonisation, they argue, resulted not only in the formation of separate Jewish land and labour markets, as well as a powerful institutional nexus centred on the Histadrut, but also in a republican-communitarian conception of citizenship that emphasised the moral value of pioneering, physical labour, agricultural settlement and military service. ${ }^{51}$ These values were not merely rhetorical or superstructural (as Nitzan and Bichler's account would imply), but were part and parcel of the 'historical bloc' constructed by the Labour Settlement Movement. Though never fully hegemonic, this Ashkenazi-led movement nonetheless managed to incorporate most Zionist groups and orientations under its sway: in Gramscian terms, it was a highly successful 'hegemonic project' ${ }^{52}$ But it also, they recognise, contained its exclusions and patterns of differential incorporation: of Mizrahim, who were economically and culturally segregated as second-class citizens; of women, who experienced the distinctive gender burdens of living in a colonial frontier society; of Israeli Palestinians, who were dispossessed of their land, proletarianised as a poor and undereducated labour force, and granted only third class civil and political rights; and of Orthodox Jews, who played a vital role in legitimating the Zionist project and were thus accorded a fair degree of latitude from Labour Zionist norms (exemption from military service, for instance). As Shafir and Peled emphasise, these patterns of exclusion and incorporation were premised not on some monocultural value consensus, but on the hegemony of a specifically Labour Zionist colonial project, which dominated Israeli society until the 1970s. 
Shafir and Peled claim that, since then, however, the Labour Settlement Movement and its republican ethos have largely dissolved, bifurcated into two rival conceptions of citizenship and identity. On the one hand, as Kimmerling also stresses, there has been an expansion in ethnonationalism, with movements like Gush Enumin inheriting much of the pioneering colonial ethos of Labour Zionism, but now dressing it up in explicitly religious garb. Yet, on the other hand, there has been a liberalisation of Israeli society in economic, social and political terms: a waning of Labour Zionist institutions like the Histadrut, including through the privatisation of state- and Histadrut-held companies; a waxing, by contrast, of liberal institutions like the Bank of Israel, the Israeli stock market and the judiciary; and an increase both in liberal individualism and income inequalities. This liberalisation, argue Shafir and Peled, has been led by an Ashkenazi elite which has "now outgrown the confines of its colonial phase of development. . . and seeks to venture out into the world' ${ }^{53}$ While this is something that the authors broadly welcome, they recognise too that economic liberalisation and the emergence of a Lockean civil society have not proven to be a panacea for Israeli society. ${ }^{54}$ They thus conclude by arguing, in Nancy Fraser's terms, for a form of democratic multiculturalism that is simultaneously cognisant of both 'recognition' and 'redistribution' questions - this carrying for them the promise not only of addressing tensions and inequalities within Israeli society, but also of resolving the conflict with the Palestinians. ${ }^{55}$

There is a great deal to be said for these arguments, and indeed for Shafir and Peled's overall theoretical perspective. While Kimmerling, on the one hand, largely neglects international and global contexts, and Nitzan and Bichler, on the other, convey little sense of the structural specificity of Israeli society, Shafir and Peled tread a midway course that analyses Israel as a colonial frontier society evolving in the face of global processes of liberalisation. While Kimmerling and Nitzan and Bichler both see elites as 'designers' and 'creators' of Israeli society, Shafir and Peled emphasise the extent to which political projects and agency are constrained by broader social forces and contradictions. ${ }^{56}$ Moreover, while the former say very little about the impact of the colonial encounter with the Palestinians on the shaping of Israel_operating with what Kimmerling has elsewhere termed a 'Jewish bubble' model of Israeli society-Shafir and Peled's account is as much about the Israeli-Palestinian conflict as it is about Israel itself. ${ }^{57}$ Finally, while Kimmerling views Israeli society as increasingly ethnonationalist but fails to discuss processes of liberalisation (aside, that is, from his stress on the emergence of cultural pluralism), Shafir and Peled insist that Israel has concurrently undergone both of these processes. All of this, and much else besides, is extremely cogent.

Having said that, Shafir and Peled do seem to overstate the extent of Israel's liberalisation and to understate, in particular, the continuing ascendancy of the military and security establishment within Israeli politics and society. Shafir and Peled argue, for instance, that, 'as the forces that shape Israeli society are becoming more global', so the prospect that the liberals will prevail 'seems to be improving'. They argue further that it will prove 'very difficult to square' a 'liberal economic vision' with the 'repressive military practices required for maintaining the occupation and defending Jewish settlers on the West Bank and 
Gaza ${ }^{58}$ Peacemaking, for them, has to a large degree been a product of liberalisation. $^{59}$ For this latter claim, Shafir and Peled adduce powerful evidence showing that Israeli business leaders, within the context of the domestic liberalisation of the Israeli capital market, were among the key advocates of peace with the Palestinians: they thus provide persuasive causal evidence that parallels and substantiates Nitzan and Bichler's statistical correlations. What they fail to acknowledge, however, is the shallowness of the Israeli business community's commitment to peace. Israel's major corporate actors have been largely uninterested in expanding trade or opening up new markets in the Occupied Territories and Middle East; on the contrary, their primary interest during the early 1990s lay in ending the secondary Arab Boycott, which penalised third parties doing business with Israel and was consequently seen as a major obstacle to attracting foreign capital. ${ }^{60}$ Israeli dominant capital, as a result, wanted peace but was not too concerned about its precise content. The upshot of this was that the peace terms imposed on the Palestinians were largely dictated not by powerful Israeli economic actors but by the Israeli military, and those terms were thus much more limited than would otherwise have been the case-amounting, in many areas, to little more than a cosmetic 'dressing up' of the Israeli occupation under the banner of 'cooperation'. ${ }^{61}$ Like Nitzan and Bichler, Shafir and Peled in the end provide little sense of the structural power of the military within Israeli society-evidenced, most obviously, in the military backgrounds of so many of the country's political leaders-or of the enormous impact the military continues to have on Israeli society and Israeli-Palestinian relations. This is a double shame, since there is no necessary reason why the power of the Israeli military could not be acknowledged and analysed within a Gramscian framework. The subject of Israeli militarism should not be overlooked simply through an aversion to statism. ${ }^{62}$

Shafir and Peled do admit that 'the victory' of Israeli liberalism is 'by no means guaranteed', but even this seems unjustifiably sanguine given the events of the past four years. ${ }^{63}$ Since summer 2000, around 3,000 Palestinians and 900 Israelis have been killed in renewed Israeli-Palestinian violence. ${ }^{64}$ The military has reassumed its place at the centre of Israeli society, and the previously disgraced Ariel Sharon has been rehabilitated as trustworthy guardian of the Israeli national interest. This has happened side by side with the launch of a new privatisation programme overseen by Binyamin Netanyahu - with little sign of it being in contradiction with repression in the West Bank and Gaza. Meanwhile in the academy, the bestknown of the New Historians, Benny Morris, seems to have become an advocate of ethnic cleansing and has given credence to Ehud Barak's frankly racist view that the Palestinians, being not of Judeo-Christian culture, do not understand the concept of truth. ${ }^{65}$ More critical voices, like that of Ilan Pappe, have found themselves ostracised within their universities and even threatened with dismissal. The study of Israeli society may have become more heterogeneous and contested, but a postcolonial liberal Israel seems almost as far away as ever.

\section{Notes}

1. The best known of the functionalist sociologies are S.N. Eisenstadt, Israeli Society (Basic Books, 1967); S.N. Eisenstadt, The Transformation of Israeli Society: An Essay in Interpretation (Wiedenfeld \& Nicolson, 


\section{Post-Zionist Perspectives on Contemporary Israel}

1985); and Dan Horowitz \& Moshe Lissak, Trouble in Utopia: The Overburdened Polity of Israel (State University of New York Press, 1989). The conventional Zionist histories were largely not written by professional historians, but by politicians, soldiers, hagiographers and so on: see Avi Shlaim, 'The Debate about 1948', International Journal of Middle East Studies, Vol. 27, No. 3 (1995), pp. 287-304, reproduced in Ilan Pappé (ed.), The Israel/Palestine Question (Routledge, 1999), pp. 171-92.

2. Leading works by Israel's 'New Historians' include Benny Morris, The Birth of the Palestinian Refugee Problem, 1947-49 (Cambridge University Press, 1987); Simha Flapan, The Birth of Israel: Myths and Realities (Croom Helm, 1987); and Avi Shlaim, Collusion Across the Jordan: King Abdullah, the Zionist Movement, and the Partition of Palestine (Clarendon, 1988). Morris's arguments are the best known (and most contested) of these; for arguments that he does not go nearly far enough in his 'revisionism', see Nur Masalha, 'A Critique of Benny Morris', Journal of Palestine Studies, Vol. 21, No. 1 (1991), pp. 90-7; and Norman Finkelstein, Image and Reality of the Israel-Palestine Conflict (Verso, 1995), ch. 3. For useful overviews of the writings of the New Historians, see Pappé, The Israel/Palestine Question; and Eugene Rogan \& Avi Shlaim (eds), The War for Palestine: Rewriting the History of 1948 (Cambridge University Press, 2001).

3. Lawrence Silberstein, The Postzionism Debate: Knowledge and Power in Israeli Culture (Routledge, 1998); and Ephraim Nimni (ed.), The Challenge of Post-Zionism: Alternatives to Israeli Fundamentalist Politics (Zed, 2003).

4. Zeev Sternhell, The Founding Myths of Israel: Nationalism, Socialism, and the Making of the Jewish State (Princeton University Press, 1998).

5. Baruch Kimmerling, The Invention and Decline of Israeliness: State, Society and the Military (University of California Press, 2001); and Gershon Shafir \& Yoav Peled, Being Israeli: The Dynamics of Multiple Citizenship (Cambridge University Press, 2002). While Kimmerling prefers not to use the term 'postZionism' (p. 7), his work can nonetheless be usefully situated within this context.

6. Jonathan Nitzan \& Shimshon Bichler, The Global Political Economy of Israel (Pluto, 2002).

7. Kimmerling, Invention and Decline, p. 2.

8. Ibid., pp. 137, 170.

9. Ibid., p. 109.

10. Ibid., p. 111.

11. Ibid., pp. 128, 169, 147.

12. Ibid., p. 173.

13. Ibid., pp. 180, 182, 209, 212. The notion of 'ethnocracy' was developed by Oren Yiftachel, especially in 'Israeli Society and Jewish-Palestinian Reconciliation: "Ethnocracy" and its Territorial Contradictions', Middle East Journal, Vol. 51, No. 4 (1997), pp. 505-19.

14. Ibid., p. 67.

15. Ibid., pp. 76-7.

16. Ibid., pp. 171, 2.

17. Peter Evans, Dietrich Rueschermeyer \& Theda Skocpol (eds), Bringing the State Back In (University of California Press, 1985).

18. Kimmerling, Invention and Decline, p. 3. Migdal develops his theory of state-society relations and his account of the Israeli state in Strong Societies and Weak States: State-Society Relations in the Third World (Princeton University Press, 1985); and Through the Lens of Israel: Explorations in State and Society (State University of New York Press, 2001). Kimmerling and Migdal are co-authors of Palestinians: The Making of a People (Free Press, 1993).

19. Ibid., pp. 72, 66, 68, 170 .

20. Ibid., p. 87. The idea of 'stateness' is derived from J.P. Nettl, 'The State as a Conceptual Variable', World Politics, Vol. 20, No. 4 (1968), pp. 559-92.

21. Baruch Kimmerling, 'The power-oriented settlement: bargaining between Israelis and Palestinians', in: M. Ma'oz \& A. Sela (eds), The PLO and Israel: From the Road to the Oslo Agreement and Back? (St. Martin's Press, 1997), pp. 223-51; Baruch Kimmerling, 'From Barak to the Road Map', New Left Review, Series 2, No. 23 (2003), pp. 134-44; and Baruch Kimmerling, Politicide: Ariel Sharon's War Against the Palestinians (Verso, 2003).

22. Kimmerling, Invention and Decline, p. 169.

23. Ibid., pp. 3, 89.

24. Horowitz \& Lissak, Trouble in Utopia; and Kimmerling, Invention and Decline, p. 84.

25. Nitzan \& Bichler, Global Political Economy, p. 8. One further debt of Kimmerling's also deserves mention here, namely, Sammy Smooha, Israel: Pluralism and Conflict (University of California Press, 1978). Smooha 
was the first leading sociologist to analyse Israeli society through a liberal pluralist lens rather than to bemoan its cultural disintegration, and Smooha's influence on Kimmerling is clear.

26. Nitzan \& Bichler, Global Political Economy, pp. 31-7; and for extended discussions of their theoretical framework, see Jonathan Nitzan, 'Differential Accumulation: Towards a New Political Economy of Capital', Review of International Political Economy, Vol. 5, No. 2 (1998), pp. 169-216; and Jonathan Nitzan \& Shimshon Bichler, "Capital accumulation: breaking the dualism of "economics" and "politics", in: Ronen Palan (ed.), Global Political Economy: Contemporary Theories (Routledge, 2000), pp. 67-88. Nitzan and Bichler draw especially upon Thorstein Veblen, The Theory of Business Enterprise (Scribner, 1904); Thorstein Veblen, Absentee Ownership and Business Enterprise in Recent Times: The Case of America (B.W. Huebsch, 1923); and Michal Kalecki, The Last Phase in the Transformation of Capitalism (Monthly Review Press, 1972). Whereas classical Marxism theorises capitalism as a mode of production and views production and labour relations as the primary source and embodiment of unequal power relations, Nitzan \& Bichler argue that 'modern capital is finance, and only finance' (p. 36) and that power and inequalities are primarily rooted in institutional control over the social process, including the power to sabotage and limit production.

27. Nitzan \& Bichler, Global Political Economy, pp. 74, 36-8.

28. Ibid., pp. 20, 40-1.

29. Ibid., p. 108.

30. Ibid., pp. 104, 117, 118. The 'dual economy' notion is developed for instance by Robert Averitt, The Dual Economy: The Dynamics of American Industry Structure (W.W. Norton, 1968); and Joseph Bowring, Competition in a Dual Economy (Princeton University Press, 1986). Nitzan and Bichler prefer to speak, though, of a 'dual political economy'.

31. Michael Bruno, Crisis, Stabilization, and Economic Reform: Therapy by Consensus (Clarendon, 1993), p. 23.

32. Nitzan \& Bichler, Global Political Economy, pp. 74, 20.

33. Ibid., pp. 24-7.

34. Ibid., pp. 128, 24.

35. Ibid., p. 266.

36. Ibid., p. 297.

37. Ibid., p. 268.

38. Shimshon Bichler \& Jonathan Nitzan, 'War Profits, Peace Dividends and the Israeli-Palestinian Conflict', News From Within, Vol. 18, No. 4 (2002), pp. 14-18. In The Global Political Economy of Israel, Nitzan and Bichler are equivocal about whether the 1990s breadth regime has given way to a new depth regime, or has merely stalled for the time being (pp. 353-7). But in more recent work they argue rather more firmly that the year 2000 seems to mark the beginning of another transition into depth: Shimshon Bichler \& Jonathan Nitzan, 'Dominant Capital and the New Wars', Journal of World-Systems Research, Vol. 10, No. 2 (2004), p. 257. Without such a change in the outlook of dominant capital, they claim, 'September 11 probably would not have become America's "new Pearl Harbor"” (ibid., p. 320).

39. Nitzan \& Bichler, Global Political Economy, p. 81.

40. Ibid., pp. 9, 267.

41. There are many aspects of Nitzan and Bichler's theory of differential accumulation that one might want to question, but let me raise just one key issue. Nitzan and Bichler hold that the main aim of individual corporations is to beat the average rate of capital income of an economy as a whole (ibid., pp. 37-8). It is this assumption which underlies their depiction of global capitalism as consisting of competing corporate coalitions. For instance, in Nitzan and Bichler's model, the 'Weapondollar-Petrodollar Coalition' consists of the major oil and arms corporations, whose common interests in instability are motivated by the desire to beat the average rate of income across the economy as a whole (as well as within dominant capital as a whole). Yet evidence would surely suggest that the averages which individual corporations are so determined to beat are not economy-wide, but are to the contrary industry benchmarks. For instance, oil majors like RoyalDutch Shell are more interested in maintaining (or if possible expanding) their share of the oil industry in particular, than in maintaining (or expanding) their share of dominant capital as a whole-for it is this intra-industrial competition which is surely the central axis of differential accumulation. If this is indeed the case, then the oil majors would have no common interest in instability, and the very idea of corporate coalitions would be untenable-and Nitzan and Bichler's entire theoretical edifice would, in turn, come tumbling down.

42. Ibid., pp. 74-5. 


\section{Post-Zionist Perspectives on Contemporary Israel}

43. On the questions of the origins of the US-Israeli special relationship and the reasons for Israel's invasions of Lebanon, see for instance Noam Chomsky's excellent accounts in Fateful Triangle: The United States, Israel and the Palestinians (Pluto, 1983), chs. 2, 5. Chomsky arguably overstates the unity of the US-Israeli relationship, but his analysis is nonetheless instructive.

44. Jonathan Nitzan, 'Regimes of Differential Accumulation: Mergers, Stagflation and the Logic of Globalization', Review of International Political Economy, Vol. 5, No. 2 (2001), pp. 226-74.

45. Bichler \& Nitzan, 'Dominant Capital and the New Wars', pp. 15, 23.

46. Nitzan \& Bichler, Global Political Economy, p. 2.

47. Ibid., p. 92.

48. Ibid., p. 17.

49. Gershon Shafir, Land, Labour and the Origins of the Israeli-Palestinian Conflict, 1882-1914 (Cambridge University Press, 1989). Kimmerling's early work also analysed the formative period of Zionist colonisation and its impact on Israeli state and society in Zionism and Territory: The Socio-Territorial Dimension of Zionist Politics (University of California Press, 1983), his Weberian account providing an interesting counter to Shafir's materialist analysis. For an excellent comparative summary of these theses, see Uri Ram, 'The Colonization Perspective in Israeli Sociology', Journal of Historical Sociology, Vol. 6, No. 3 (1993), pp. 327-50, reproduced in Pappé, The Israel/Palestine Question, pp. 56-80. Shafir and Kimmerling, it should be said, were not the first to write of Israel in these terms. The colonisation perspective is a commonplace of Palestinian accounts—see, for instance, Elia Zureik, The Palestinians in Israel: A Study in Internal Colonialism (Routledge \& Kegan Paul, 1978) — and was also famously formulated by Maxime Rodinson in Israel: A Colonial-Settler State? (Monad, 1973). But Shafir and Kimmerling were the first to introduce such perspectives into mainstream Israeli sociology.

50. Michael Shalev, 'Jewish organised labour and the Palestinians: a study of state/society relations in Israel', in: Baruch Kimmerling (ed.), The Israeli State and Society: Boundaries and Frontiers (State University of New York Press, 1989), p. 95. The notion of the 'split labour market' is developed by Edna Bonacich, 'A Theory of Ethnic Antagonism: The Split Labour Market', American Sociological Review, Vol. 37, No. 5 (1972), pp. 547-59, and applied to Israel by Shafir, Land, Labour and the Origins of the Israeli-Palestinian Conflict, pp. 15-16, 55-60.

51. Shafir \& Peled, Being Israeli, p. 17.

52. Ibid., p. 66; and Antonio Gramsci, Selections from the Prison Notebooks (Lawrence \& Wishart, 1977).

53. Ibid., p. 339.

54. Ibid., p. 342.

55. Ibid., p. 343; and Nancy Fraser, 'From Redistribution to Recognition? Dilemmas of Justice in a "Post-Socialist Age", New Left Review, No. 212 (1995), pp. 68-93.

56. Kimmerling, Invention and Decline, pp. 6, 229.

57. Baruch Kimmerling, 'Boundaries and frontiers of the Israeli control system', in: Kimmerling, The Israeli State and Society, p. 270.

58. Ibid., p. 342.

59. This thesis is explored in Shafir \& Peled, Being Israeli, ch. 9, but also in Gershon Shafir \& Yoav Peled (eds), The New Israel: Peacemaking and Liberalization (Westview, 2000); and Yoav Peled \& Gershon Shafir, 'The Roots of Peacemaking: The Dynamic of Citizenship in Israel', International Journal of Middle Eastern Studies, Vol. 27, No. 3 (1996), pp. 391-413.

60. Shafir and Peled recognise this (Being Israeli, p. 258), but do not sufficiently consider its implications. See also on Israeli business interests Markus Bouillon, The Peace Business: Money and Power in the Palestine-Israel Conflict (IB Tauris, 2004), especially pp. 51-9.

61. I develop these points more fully in Water, Power and Politics in the Middle East: The Other IsraeliPalestinian Conflict (IB Tauris, 2003), chs. 4 and 6; and 'Dressing up Domination as "Cooperation": The Case of Israeli-Palestinian Water Relations', Review of International Studies, Vol. 29, No. 1 (2003), pp. 21-38.

62. On this subject, see in particular Uri Ben-Eliezer, The Making of Israeli Militarism (Indiana University Press, 1998).

63. Shafir \& Peled, Being Israeli, p. 259.

64. Figures from B'Tselem at http://www.btselem.org/ for the period 29 September 2000 to 30 September 2004.

65. 'A Jewish state would not have come into being without the uprooting of 700,000 Palestinians. Therefore it was necessary to uproot them. There was no choice but to expel that population ... You can't make an omelette without breaking eggs. You have to dirty your hands' (Morris in interview with Ari Shavit, 


\section{Jan Selby}

'Survival of the Fittest', Ha'aretz, 9 January 2004). For discussion, see Joel Beinin, 'No More Tears: Benny Morris and the Road Back from Liberal Zionism', Middle East Report, Vol. 34, No. 1 (2004), pp. 38-47. The Palestinians, Barak claims, 'are the products of a culture in which to tell a lie ... creates no dissonance. They don't suffer from the problem of telling lies that exists in Judeo-Christian culture.

Truth is seen as an irrelevant category' (in Benny Morris, 'Camp David and After: An Interview with Ehud Barak', New York Review of Books, 13 June 2002). 